\title{
Bladder PEComa
}

National Cancer Institute

\section{Source}

National Cancer Institute. Bladder PEComa. NCI Thesaurus. Code C159673.

A benign or malignant perivascular epithelioid cell tumor arising from the bladder. 